\title{
Inorganic carbon removal and isotopic enrichment in Antarctic sea ice gap layers during early austral summer
}

\author{
S. Papadimitriou ${ }^{1, *}$, D. N. Thomas ${ }^{1}$, H. Kennedy ${ }^{1}$, H. Kuosa ${ }^{2}$, G. S. Dieckmann ${ }^{3}$ \\ ${ }^{1}$ Ocean Sciences, College of Natural Sciences, Bangor University, Menai Bridge, Anglesey LL59 5AB, UK \\ ${ }^{2}$ Tvärminne Zoological Station, University of Helsinki, 109100 Hanko, Finland \\ ${ }^{3}$ Alfred Wegener Institute for Polar and Marine Research, Am Handelshafen 12, 27570 Bremerhaven, Germany
}

\begin{abstract}
The biogeochemical composition of 2 spatially separate surface gap layers on a single Antarctic sea ice floe during early austral summer was predominantly controlled by the growth of diatoms and, especially, Phaeocystis. These algal communities in and near the gap layers imposed large geochemical changes in the chemical and isotopic composition of the gap waters, typical of intense autotrophic activity. These included a large deficit in all major dissolved inorganic nutrients (dissolved inorganic carbon $\left[\mathrm{C}_{\mathrm{T}}\right]$, nitrate, soluble reactive phosphorus, silicic acid), $\mathrm{O}_{2}$ accumulation above air saturation, large $\mathrm{pH}$ shifts into the alkaline spectrum, and a large, closely coupled ${ }^{13} \mathrm{C}$ enrichment of the $\mathrm{C}_{\mathrm{T}}$ pool and the accumulated particulate organic carbon, in all cases relative to the composition of surface oceanic water. The amount of inorganic carbon removed from the gap water exceeded that which can be predicted from the deficits of dissolved inorganic nitrogen or phosphorus and the elemental composition of the biogenic matter suspended in it or the mean elemental composition of oceanic phytoplankton. This stoichiometric deviation suggests either (1) the operation of the inorganic carbon overconsumption mechanism via the biological production of particular classes of intra- or extracellular carbon rich compounds, or (2) substantial utilisation of ammonium and urea as autotrophic nitrogen sources in addition to nitrate, or (3) both.
\end{abstract}

KEY WORDS: Antarctica · Sea ice · Gap layers · Biogeochemistry Nutrients · Particulate organic matter $\cdot$ Carbon isotopic composition

\section{INTRODUCTION}

Surface gap layers are commonly found in Antarctic sea ice in austral spring and summer (Garrison \& Buck 1991, Ackley \& Sullivan 1994, Haas et al. 2001, Garrison et al. 2005, Ackley et al. 2008) as structural discontinuities that consist of a spatially extensive void between internal ice surfaces filled with a mixture of seawater and meltwater (for a comprehensive schematic representation, see Haas et al. 2001). Gap layers develop near the freeboard of ice floes through physical processes, such as snow accumulation and internal melting, while their water exchanges regularly with the ambient surface oceanic water by wave action (Haas et al. 2001, Ackley et al. 2008). They are complex systems where direct biogeochemical exchange becomes possible between the otherwise isolated upper sea ice column and the surface ocean (Kennedy et al. 2002, Kattner et al. 2004), operating much like the ice-seawater boundary in the lower part of ice floes but at higher incident irradiance. In the context of sea ice ecology, surface gap layers form a well-illuminated habitat in comparison to the underlying and increasingly more shaded internal and bottom sea ice communities. Surface gap layers in sea ice have drawn the attention of physicists, biologists, geochemists, and modellers on account of their widespread occurrence, tantamount to considerable areal 
extent seasonally, and their copious biological productivity (Fritsen et al. 1994, 1998, 2001, Arrigo et al. 1997, Kennedy et al. 2002, Kattner et al. 2004, Garrison et al. 2005).

Seawater infiltration and the sufficient incident irradiance near the ice surface ensure favourable conditions with respect to light and nutrient availability for biological production, resulting in the development of dense autotrophic communities in the topmost sea ice layers from spring until autumn (Garrison \& Buck 1991, Fritsen et al. 1994, Kennedy et al. 2002). The biological productivity of surface sea ice communities in and around gap layers is the highest in the Antarctic seasonal ice zone (SIZ; Kottmeier \& Sullivan 1990, Garrison \& Buck 1991, Lizotte \& Sullivan 1991, Fritsen et al. 1994, Gleitz et al. 1996b), resulting in the annual fixation of an estimated $40 \mathrm{Tg}$ of carbon into biomass (Arrigo et al. 1997). The inoculum of the surface sea ice communities originates in internal sea ice assemblages recruited from the surface oceanic water during sea ice formation, and with the organisms in the infiltrating surface seawater. As with the whole of the pack ice as a habitat, the assemblages in surface layers are dominated by a small number of algal species, typically diatoms and the prymnesiophyte Phaeocystis (Garrison \& Buck 1991, Gleitz et al. 1996a, Garrison et al. 2005).

Sea ice habitats in the interior and the surfaces of ice floes function like closed biological systems, exhibiting a host of geochemical signatures symptomatic of net autotrophic environments, often to their extreme by comparison with productive open oceanic waters (Gleitz et al. 1995, Kennedy et al. 2002, Papadimitriou et al. 2007). Their geochemical profile is therefore typically characterised by reduced concentrations of the major dissolved inorganic macro-nutrients, including total dissolved inorganic carbon $\left(\mathrm{C}_{\mathrm{T}}\right)$ and dissolved carbon dioxide $\left(\mathrm{CO}_{2}[\mathrm{aq}]\right)$, due to uptake for biosynthesis, elevated dissolved molecular oxygen $\left(\mathrm{O}_{2}\right)$ as a product of photosynthesis and elevated $\mathrm{pH}$ via the biological $\mathrm{CO}_{2}$ drawdown. Concurrently, the residual $\mathrm{C}_{\mathrm{T}}$ pool can become enriched in ${ }^{13} \mathrm{C}$, resulting in an increased ratio of ${ }^{13} \mathrm{C}$ to ${ }^{12} \mathrm{C}\left(\delta^{13} \mathrm{C}_{\mathrm{T}}\right)$, due to the mass-dependent biological isotopic fractionation of the cellular, carbon-fixing reactions leading to kinetically faster ${ }^{12} \mathrm{C}$ assimilation into biomass by autotrophic organisms (Fogel \& Cifuentes 1993). There have been indications of excess inorganic carbon deficit due to biological production in sea ice habitats relative to inorganic nitrogen and phosphorus as compared to the Redfield elemental stoichiometric composition (C:N:P = 106:16:1), or the concurrent elemental composition, of biogenic particles (Gleitz et al. 1995, 1996a, Kennedy et al. 2002, Papadimitriou et al. 2007).
Sea ice presents a dauntingly heterogeneous medium for the interpretation of it as a habitat, but the biogeochemical composition of gap waters can act as an integrator of in situ biological activity over a radius extending well into the surrounding sea ice layers (Kennedy et al. 2002, Kattner et al. 2004). Recent work has compiled physical, biological and chemical characteristics of surface gap layers during late austral summer and autumn from a large number of ice floes over a considerable expanse of the Bellingshausen, Amundsen, Weddell and Ross seas of Antarctica (Haas et al. 2001, Kennedy et al. 2002, Garrison et al. 2003, 2005, Kattner et al. 2004). The current study was conducted during the interdisciplinary field experiment Ice Station POLarstern (ISPOL; Hellmer et al. 2006, 2008) and monitored the biogeochemical composition of gap layers in the transition from spring to summer under the well-constrained conditions of a single ice floe. We hypothesised that the combined geochemical and biological monitoring in the minimised spatial scale of a single ice floe would provide temporal resolution of the biogeochemical changes generated by the activity of surface assemblages during the initial stages of gap formation in Antarctic sea ice earlier in the growing season than previous studies. Further, the occurrence of 2 spatially and morphologically distinct gap systems on the ISPOL floe provided the opportunity for a comparative investigation. The objective was to examine the dissolved and particulate constituents of the mostly hyposaline aqueous phase of the 2 major surface gap layers on the ISPOL floe, in order to improve our understanding of the mechanisms that result in the extreme biogeochemical characteristics of such a varied environment.

\section{MATERIALS AND METHODS}

Study site and sampling. The study was conducted on a $10 \times 10 \mathrm{~km}$ (initial dimensions) ice floe in the western Weddell Sea in December 2004 at approximately 67 to $68^{\circ} \mathrm{S}$ and $55^{\circ} \mathrm{W}$. Details of the geographical, physical and chemical features of the floe have been reported by Papadimitriou et al. (2007), Haas et al. (2008), and Lannuzel et al. (2008). All measurements described here were obtained between Days 353 (18 December) and 366 (31 December) of the year from the aqueous phase of 2 spatially separate gap layers located within the top 10 to $30 \mathrm{~cm}$ of the floe. One of the gap layers overlay thick first-year ice and was located in a $10 \times 10 \mathrm{~m}$ surface depression approximately $100 \mathrm{~m}$ from the edge of the floe without a visible algal colouration. The second gap layer was stained dark brown by the resident algal assemblage and overlay second-year ice. The gap layer in the first- 
year ice (GL\#1) was narrower and under a thinner snow cover than the gap layer on top of the secondyear ice (GL\#2; Table 1).

Gap water samples for biological observations and for the determination of $\mathrm{O}_{2}$, total alkalinity $\left(\mathrm{A}_{\mathrm{T}}\right), \mathrm{C}_{\mathrm{T}}$, $\delta^{13} \mathrm{C}_{\mathrm{T}}$, dissolved organic carbon (DOC), dissolved ammonium $\left(\mathrm{NH}_{4}{ }^{+}\right)$, nitrate plus nitrite (hereafter, nitrate $\left[\mathrm{NO}_{3}{ }^{-}\right]$), soluble reactive phosphorus (SRP), and molybdate-reactive silicon (hereafter, silicic acid $\left.\left[\mathrm{Si}(\mathrm{OH})_{4}\right]\right)$ were collected as described by Papadimitriou et al. (2007). The bulk gap water samples collected for the determination of $\mathrm{DOC}, \mathrm{NH}_{4}{ }^{+}$and the major dissolved inorganic nutrients were first passed through a $1 \mathrm{~mm}^{2}$ mesh into acid-washed polyethylene containers to remove ice crystals (slush) and were transported to the onboard laboratory for immediate filtration through pre-combusted $\left(550^{\circ} \mathrm{C}\right.$ for $\left.3 \mathrm{~h}\right) \mathrm{GF} / \mathrm{F}$ filters (Whatman). The filters were kept at $-20^{\circ} \mathrm{C}$ for the determination of chlorophyll a ( $\mathrm{chl} a$ ) in the onboard laboratory and for further particulate organic matter analyses in the home laboratory. Urea was determined in similarly filtered subsamples, kept at $-20^{\circ} \mathrm{C}$ in $20 \mathrm{ml}$ acid-washed polypropylene scintillation vials until analysis in the home laboratory, and is reported as urea-bound nitrogen (urea-N).

Methodology. Temperature ( $\mathrm{T}$ ) was measured in situ with a calibrated K-Thermocouple probe on a HANNA Instruments thermometer (HI93530). Salinity (S) was measured at laboratory temperature (17 to $22^{\circ} \mathrm{C}$ ) using a portable conductivity meter (SEMAT
Cond 315i/SET) with a WTW Tetracon 325 probe. Details of the methodology followed for cell counting and the identification of organisms (protists), as well as for the analysis of chl $a, \mathrm{O}_{2}, \mathrm{NH}_{4}{ }^{+}, \mathrm{NO}_{3}{ }^{-}, \mathrm{SRP}, \mathrm{Si}(\mathrm{OH})_{4}$, DOC, $A_{T}, C_{T}$ and $\delta^{13} C_{T}$ are given by Papadimitriou et al. (2007). The average cell volume was estimated by measuring the dimensions of about 30 cells on an ocular grid and using standard geometrical shapes. The biomass volume of protists was estimated from the cell concentration and average cell volume obtained from the microscopic counts for each species. The urea-N concentration was determined using the diacetyl monoxime method of Price \& Harrison (1987) adapted for flow injection analysis on a LACHAT Instruments Quick-Chem 8000 autoanalyser. The particulate organic carbon (POC), its stable isotopic composition $\left(\delta^{13} \mathrm{C}_{\mathrm{POC}}\right)$ and particulate nitrogen $(\mathrm{PN})$ were determined using the methods described by Kennedy et al. (2002). Water $\delta^{18} \mathrm{O}$ analysis was conducted by off-line equilibration with $\mathrm{CO}_{2}$ and subsequent measurement of the oxygen isotope ratios using a PDZ-EUROPA GEO 20/20 mass spectrometer, with normalisation relative to North Sea seawater (accepted value: $+0.132 \%$ ). The precision of replicate $\delta^{18} \mathrm{O}$ analyses was $0.06 \%$, and all data are reported in per mil (\%) relative to Standard Mean Ocean Water (SMOW). The concentration of dissolved carbon dioxide $\left[\mathrm{CO}_{2}(\mathrm{aq})\right]$ and $\mathrm{O}_{2}$ at atmospheric equilibrium (i.e. $100 \%$ air saturation), as well as the $\mathrm{pH}$ on the seawater scale $\left(\mathrm{pH}_{\mathrm{Sws}}\right)$ and the in situ $\left[\mathrm{CO}_{2}(\mathrm{aq})\right]$ were computed at the in situ

Table 1. Thickness of gap, superimposed ice (si; frozen snowmelt), and snow layers (all in $\mathrm{cm})$, salinity (S), temperature (T), salinity-normalised concentration of dissolved species (all in $\mu \mathrm{mol} \mathrm{kg}{ }^{-1}$ ), measured chlorophyll a (chl $a$, in $\mu$ g kg ${ }^{-1}$ ), particulate organic carbon (POC), and particulate nitrogen (PN) concentrations (both in $\mu \mathrm{mol} \mathrm{kg}^{-1}$ ), POC:PN (molar), and POC:chl a (mass) in water from gap layer $1(\mathrm{GL \# 1)}(\mathrm{n}=14)$ and GL\#2 $(\mathrm{n}=9)$, and from contemporaneous surface seawater

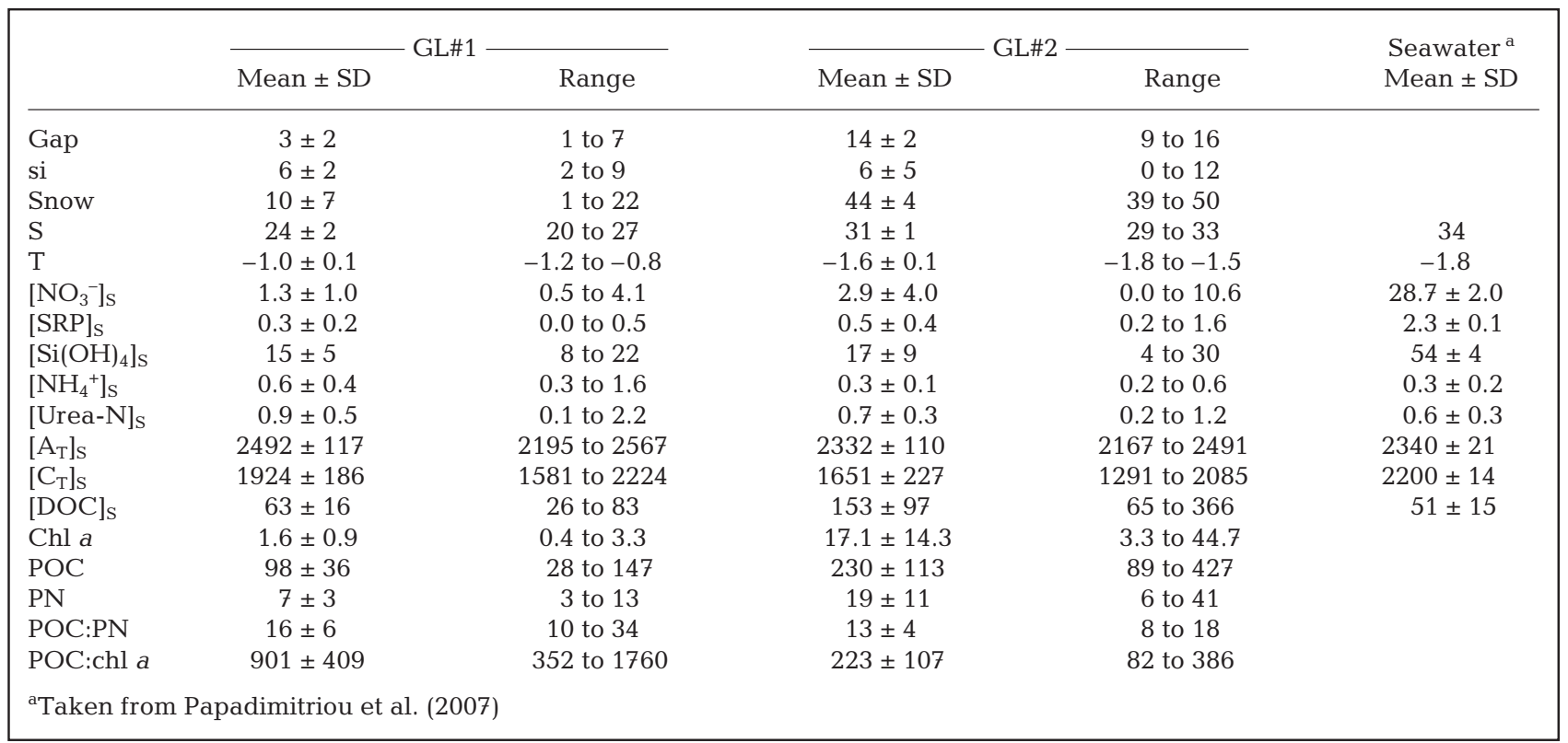


T and S as described by Papadimitriou et al. (2007). All computations required extrapolation to the in situ $\mathrm{T}$ of the existing empirical thermodynamic equations developed for above-zero temperatures. The extrapolation is bound to yield uncertainty in the computations due to the non-linearity of the equations, which is unknown due to lack of experimental data at sub-zero temperatures. Nonetheless, the extrapolation to subzero temperatures is a realistic approach for media of ionic composition and temperature outside the range of existing empirical thermodynamic data (Marion 2001). Correlation and variance analyses (ANOVA) were conducted in MINITAB, while regression analysis was based on the geometric mean regression method (Ricker 1973).

\section{RESULTS}

\section{Origin of water in surface gap layers}

All water samples were less saline and warmer than surface seawater. The sampling locations were distinct from each other with respect to $\mathrm{S}-\mathrm{T}$, with water from GL\#2 being colder and more saline than the water from GL\#1. The $\delta^{18} \mathrm{O}$ of the gap water was close to (GL\#2: $-0.5 \%, \mathrm{n}=1$ ) or depleted (GL\#1: $-5.0 \pm 2.1 \%$, $\mathrm{n}$ $=7)$ relative to surface seawater $(-0.36 \pm 0.03 \%, \mathrm{n}=5)$. The $\delta^{18} \mathrm{O}$ of snow, known to be significantly depleted relative to the source oceanic water in low latitudes as a result of isotopic fractionation during evaporation, ranged from $-17 \%$ to $-13 \%$ on the ISPOL floe, while the $\delta^{18} \mathrm{O}$ of bulk ice and internal brine ranged from +0.7 to $+1.9 \%$ and from -1.3 to $-0.6 \%$, respectively (Tison et al. 2008). Although some input from the underlying sea ice via internal melting cannot be precluded, the contribution from ${ }^{18} \mathrm{O}$-depleted water from snow melt is clearly indicated in the $\delta^{18} \mathrm{O}$ of the least saline samples from GL\#1. This suggests that the ionic composition of the samples derived from surface seawater was variably modified by dilution with snow meltwater. The chemical and isotopic composition of surface seawater (Table 1), presented by Papadimitriou et al. (2007), will be used hereafter as a reference point.

Typically, solute concentrations $\left(\mathrm{C}_{\text {measured }}\right)$ in aqueous media of widely varying salinity $\left(\mathrm{S}_{\text {measured }}\right)$ from sea ice environments are evaluated against a simple linear model of physical modification (concentration or dilution) of seawater of known solute concentration $\left(\mathrm{C}_{\text {seawater }}\right)$ and salinity $\left(\mathrm{S}_{\text {seawater }}\right)$ by an ion- and gasfree medium (ice or snow meltwater, respectively; Gleitz et al. 1995, Kennedy et al. 2002, Papadimitriou et al. 2007). Potential deviation $\left(\Delta C_{1}\right)$ of the salinitynormalised $\mathrm{C}_{\text {measured }}$ (i.e. $\mathrm{C}_{\mathrm{S}}$ ) from simple physical modification of $\mathrm{C}_{\text {seawater }}$ can then be modelled as in Eq. (1). Using the same concept, direct modelling of non-normalised $\mathrm{C}_{\text {measured }}$ can be done as in Eq. (2). Because $C_{S}$ is directly comparable to $C_{\text {seawater }}$ (Eq. 1), the current observations of solute concentrations are presented and discussed as such.

$$
\begin{gathered}
\mathrm{C}_{\mathrm{s}}=\frac{\mathrm{S}_{\text {seawater }}}{\mathrm{S}_{\text {measured }}} \mathrm{C}_{\text {measured }}=\mathrm{C}_{\text {seawater }}+\Delta \mathrm{C}_{1} \\
\mathrm{C}_{\text {measured }}=\frac{\mathrm{S}_{\text {measured }}}{\mathrm{S}_{\text {seawater }}} \mathrm{C}_{\text {seawater }}+\Delta \mathrm{C}_{2}
\end{gathered}
$$

The concentration change $(\Delta \mathrm{C})$ due to biological activity in a medium generated by the mixing of 2 water masses will depend on the complex and dynamic interplay of the physical and biological processes prior to observation. It is not known at which point biological uptake occurred during the dilution of surface seawater with snow meltwater in the gap layers. In this context, salinity normalisation (Eq. 1) describes uptake at $\mathrm{C}_{\text {seawater }}$ and $\mathrm{S}_{\text {seawater }}$ followed by dilution of the residual concentration to $\mathrm{C}_{\text {measured }}$ and $\mathrm{S}_{\text {measured, with }} \Delta \mathrm{C}=$ $\Delta C_{1}$. Eq. (2) describes the reverse sequence of events, i.e. dilution of $\mathrm{C}_{\text {seawater }}$ and $\mathrm{S}_{\text {seawater }}$ to $\mathrm{S}_{\text {measured }}$ followed by uptake of the diluted solute at $\mathrm{S}_{\text {measured }}$ to $\mathrm{C}_{\text {measured, }}$ with $\Delta \mathrm{C}=\Delta \mathrm{C}_{2}$. These 2 scenarios represent the 2 extremes of a more intricate, multi-step relationship between dilution and biological uptake that cannot be unravelled by the current measurements. In either case, $\Delta \mathrm{C}<0$ signifies relative solute depletion and $\Delta \mathrm{C}$ $>0$ solute enrichment, but, from Eqs. (1) and (2) above, it follows that $\Delta \mathrm{C}_{1}$ is the salinity-normalised $\Delta \mathrm{C}_{2}$, and $\Delta \mathrm{C}_{1}>\Delta \mathrm{C}_{2}$ for $\left(\mathrm{S}_{\text {seawater }} / \mathrm{s}_{\text {measured }}\right)>1$. In short, it is not possible to know the exact magnitude of $\Delta \mathrm{C}_{i}$ only the $\Delta \mathrm{C}$ ratio of 2 solutes can be meaningful in this case. The $\mathrm{pH}_{\mathrm{SwS}}$ and the concentration of dissolved gases, $\mathrm{O}_{2}$ and $\mathrm{CO}_{2}(\mathrm{aq})$, are more complex functions of $\mathrm{S}$ and $\mathrm{T}$ because of their direct dependence on the thermodynamic equilibria of gas exchange and acid-base reactions in the medium. Consequently, these parameters cannot be normalised in a simple manner, and are presented and discussed as measured.

\section{Chemical composition}

The ranges of the measured concentrations of the major dissolved inorganic nutrients were 0.3 to $10.4 \mu \mathrm{mol} \mathrm{NO}{ }_{3}{ }^{-} \mathrm{kg}^{-1}, 0.0$ to $1.4 \mu \mathrm{mol} \mathrm{SRP} \mathrm{kg}{ }^{-1}$ and 4 to $28 \mu \mathrm{mol} \mathrm{Si}(\mathrm{OH})_{4} \mathrm{~kg}^{-1}$. Their salinity-normalised concentrations $\left(\left[\mathrm{NO}_{3}{ }^{-}\right]_{\mathrm{S}}, \quad[\mathrm{SRP}]_{\mathrm{S}}\right.$, and $\left.\left[\mathrm{Si}(\mathrm{OH})_{4}\right]_{\mathrm{S}}\right)$ were lower than surface seawater by an order of magnitude for $\mathrm{NO}_{3}{ }^{-}$and $\mathrm{SRP}$, and by a factor of 3 to 4 for $\mathrm{Si}(\mathrm{OH})_{4}$ on average (Table 1). The measured concentrations of $\mathrm{NH}_{4}{ }^{+}$ranged from 0.2 to $1.1 \mu \mathrm{mol} \mathrm{kg}{ }^{-1}$, with the salin- 
ity-normalised concentrations $\left(\left[\mathrm{NH}_{4}{ }^{+}\right]_{\mathrm{S}}\right)$ mostly within the range measured in surface seawater (Table 1), except for a relative enrichment by a factor of 2 to 4 in individual GL\#1 samples $(\mathrm{n}=3)$. The concentration of urea-N varied from 0.1 to $2.2 \mu \mathrm{mol} \mathrm{kg}{ }^{-1}$, with salinitynormalised concentrations being higher than surface seawater by a factor of 1.5 to 5.0 in $60 \%$ of the samples and within the range of surface seawater concentrations or relatively depleted in the remaining $40 \%$ of the samples.

The measured $\mathrm{A}_{\mathrm{T}}$ concentrations ranged from 1512 to $2248 \mu \mathrm{mol} \mathrm{eq} \mathrm{kg}^{-1}$, with salinity-normalised concentrations $\left(\left[\mathrm{A}_{\mathrm{T}}\right]_{\mathrm{S}}\right)$ exhibiting random variability about the mean surface seawater $A_{T}$ within $\pm 200 \mu \mathrm{mol} \mathrm{eq} \mathrm{kg}^{-1}$ (Table 1). The measured $\mathrm{C}_{\mathrm{T}}$ concentrations ranged from 1059 to $1911 \mu \mathrm{mol} \mathrm{kg}{ }^{-1}$, with salinity-normalised concentrations $\left(\left[\mathrm{C}_{\mathrm{T}}\right]_{\mathrm{S}}\right)$ reduced relative to the surface seawater concentration (Table 1 ). The $\delta^{13} C_{\mathrm{T}}$ varied from $+2.0 \%$ to $+10.9 \%$ and was more positive than in the surface seawater $\left(\delta^{13} \mathrm{C}_{\mathrm{T}, \mathrm{SW}}=+0.5 \pm 0.3 \%\right.$, indicating a large ${ }^{13} \mathrm{C}$ enrichment of the $\mathrm{C}_{\mathrm{T}}$ pool of the gap
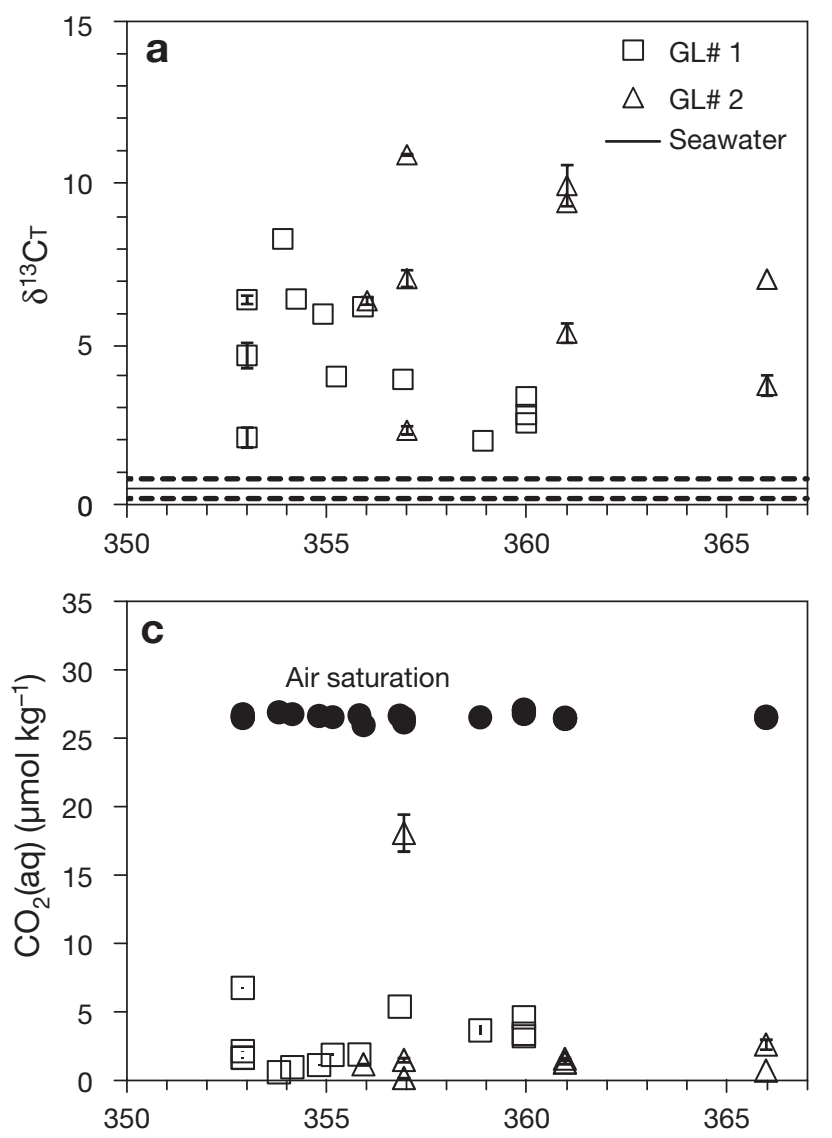

waters by $+1.5 \%$ o to $+10.4 \%$ (Fig. $1 \mathrm{a}$ ). The $\mathrm{pH}_{\mathrm{SwS}}$ ranged from 8.49 to 9.65 and was higher (more alkaline) than in the surface seawater by 0.32 to 1.48 units, with the exception of a single GL\#2 sample that yielded a $\mathrm{pH}_{\mathrm{SWS}}$ of 8.11 and $8.17(\mathrm{n}=2)$, similar to that in surface seawater (Fig. 1b). The calculated concentration of $\mathrm{CO}_{2}$ (aq) ranged from 0.1 to $6.8 \mu \mathrm{mol} \mathrm{kg}{ }^{-1}$, except for the GL\#2 sample with the $\mathrm{pH}_{\mathrm{Sws}}$ minimum, which yielded a $\left[\mathrm{CO}_{2}(\mathrm{aq})\right]$ of 16.7 and $19.4 \mu \mathrm{mol} \mathrm{kg}{ }^{-1}(\mathrm{n}=2)$. These observations were equivalent to 1 to $25 \%$ saturation with respect to equilibrium with air, except for the $\mathrm{pH}_{\text {SwS }}$ minimum sample, which was $68 \%$ saturated with $\mathrm{CO}_{2}$ with respect to air equilibrium (Fig. 1c). The measured $\mathrm{O}_{2}$ concentration ranged from 421 to

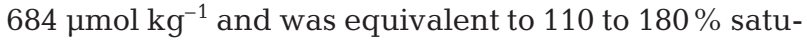
ration with respect to air equilibrium (Fig. 1d).

The measured concentration of DOC varied from 19 to $324 \mu \mathrm{mol} \mathrm{kg} \mathrm{kg}^{-1}$, while the salinity-normalised concentrations $\left([\mathrm{DOC}]_{\mathrm{S}}\right)$ were within the range of concentrations measured in the surface seawater in GL\#1 but were mostly enriched by comparison in GL\#2 by up to
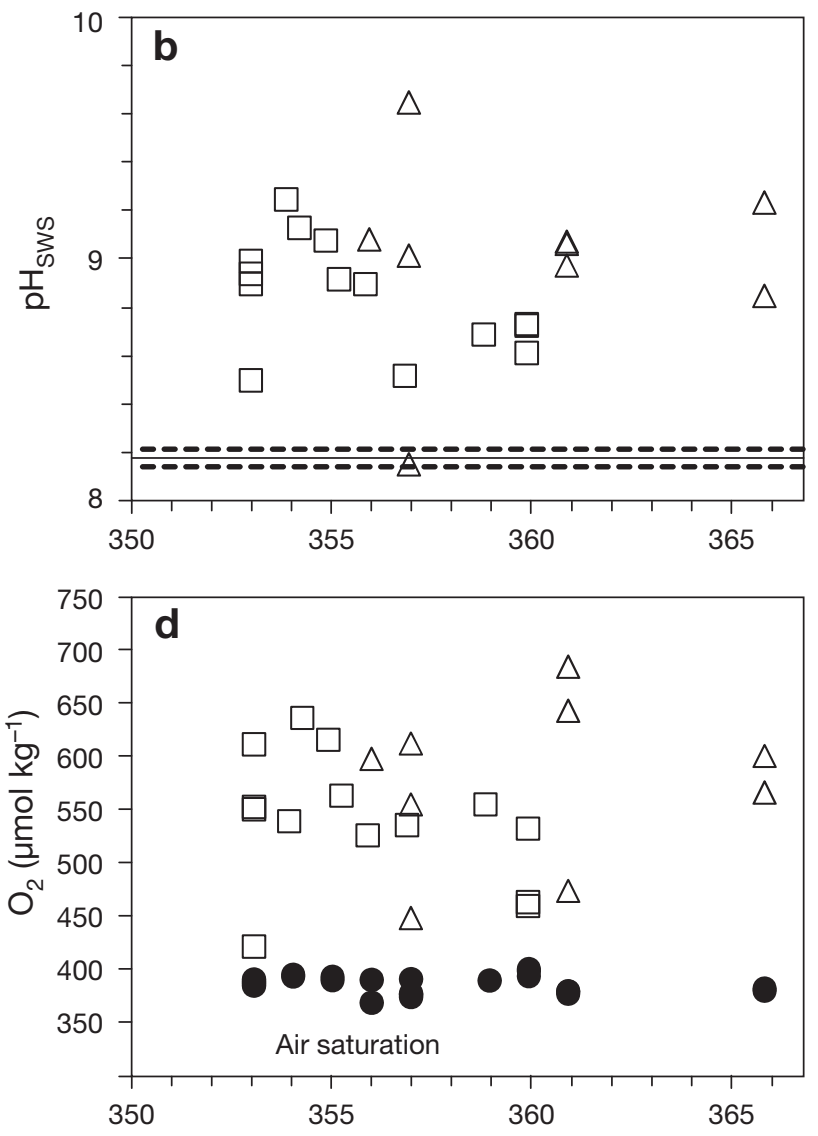

Day of the year

Fig. 1. (a) Stable isotope composition of total dissolved inorganic carbon $\delta^{13} \mathrm{C}_{\mathrm{T}}$, (b) $\mathrm{pH}$ on the seawater scale (pH $\mathrm{pHs}_{\mathrm{SwS}}$, (c) dissolved $\mathrm{CO}_{2}$ and (d) dissolved molecular oxygen $\mathrm{O}_{2}$ versus day of the year. Error bars represent the range of duplicate measurements. Dashed lines in (a) and (b) indicate \pm SD from the mean value for surface seawater, indicated by the solid line. Filled circles in (c) and (d) indicate concentration in the gap waters at saturation with respect to equilibrium with air at the in situ $\mathrm{S}$ and $\mathrm{T}$ 
a factor of 7 (Table 1). The concentration of POC and PN ranged over 1 order of magnitude, from 28 to $427 \mu \mathrm{mol} \mathrm{kg} \mathrm{kg}^{-1}$ and from 3 to $41 \mu \mathrm{mol} \mathrm{kg}{ }^{-1}$, respectively. The POC and PN were significantly correlated $(\mathrm{r}=$ 0.909, $\mathrm{p}<0.001, \mathrm{n}=23$ ), and the slope of the linear regression yielded an average POC:PN = $11 \pm 2$ (measured range: 10 to 34 ; Table 1). The concentration of chl a ranged over 2 orders of magnitude from 0.4 to $44.7 \mu \mathrm{g} \mathrm{kg}^{-1}$ and tended to be higher in GL\#2 than in GL\#1 (Table 1). Chl a correlated significantly with POC following logarithmic transformation of the data $\left(\mathrm{r}_{\log -\log }=0.862, \mathrm{p}<0.001, \mathrm{n}=23\right)$. The resulting power function, $[\mathrm{POC}]=72[\mathrm{chl} \mathrm{a}]^{0.5 \pm 0.1}$, suggests a decreasing POC:chl with increasing chl a concentration (measured POC:chl range: 82 to 1760), with distinctly lower ratios in GL\#2 than in GL\#1 (Table 1). The $\delta^{13} \mathrm{C}_{\mathrm{POC}}$ ranged from $-25.0 \%$ to $-16.6 \%$, with higher (more enriched in ${ }^{13} \mathrm{C}$ ) values in GL\#2 (mean $\pm 1 \mathrm{SD}:-18.8 \pm$ $1.3, \mathrm{n}=9)$ than in GL\#1 $(-22.0 \pm 1.9, \mathrm{n}=14)$.

\section{Biological composition}

The protist community was predominantly autotrophic, which accounted for $94 \pm 7 \%$ and $99 \pm 1 \%$ of the total observed protist biomass in GL\#1 and GL\#2, respectively. The remainder comprised small heterotrophic ciliates and bacterivorous flagellates. The autotrophic protist community was composed of small diatoms (Fragilariopsis cylindrus, Nitzschia sp., Chaetoceros sp.: $10 \mu^{3}$ cell volume; Pseudonitzschia spp., Cylindrotheca closterium: $25 \mu^{3}$ ), large diatoms (Amphipora sp., Nitzschia sp.: $500 \mu^{3}{ }^{3}$ Pinnularia sp.: $1000 \mathrm{\mu m}^{3}$ ), autotrophic flagellates (Mantoniella sp.:

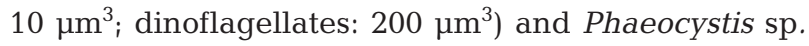
$\left(10 \mathrm{~m}^{3}\right)$, as well as the cryptophyte chloroplastcontaining, symbiotic ciliate Mesodinium rubrum $\left(1500 \mathrm{~m}^{3}\right)$ in very small cell numbers. The relative cell concentration indicates dominance $(\geq 50 \%$ of the total cell concentration) of small diatoms, with significant and equivalent contribution by Phaeocystis and flagellates to the species abundance in GL\#1, and dominance of Phaeocystis, with significant contribution by small diatoms in GL\#2 (Fig. 2a). On average, $15 \pm 18 \%$ and $26 \pm 23 \%$ of the Phaeocystis cell concentration in GL\#1 and GL\#2, respectively, were observed in colonies, each colony being approximately $1000 \mathrm{\mu m}^{3}$ and containing 70 cells on average. Based on the total biomass volume contributed by each species of the autotrophic protists, small diatoms dominated GL\#1 (48 \pm $17 \%)$ and large diatoms dominated GL\#2 (51 $\pm 26 \%)$, with Phaeocystis contributing equally in both gaps ( $23 \pm 17 \%$ and $21 \pm 19 \%$, respectively) and the remainder of the biomass volume contributed to by autotrophic flagellates (Fig. 2b). Following logarithmic transforma-

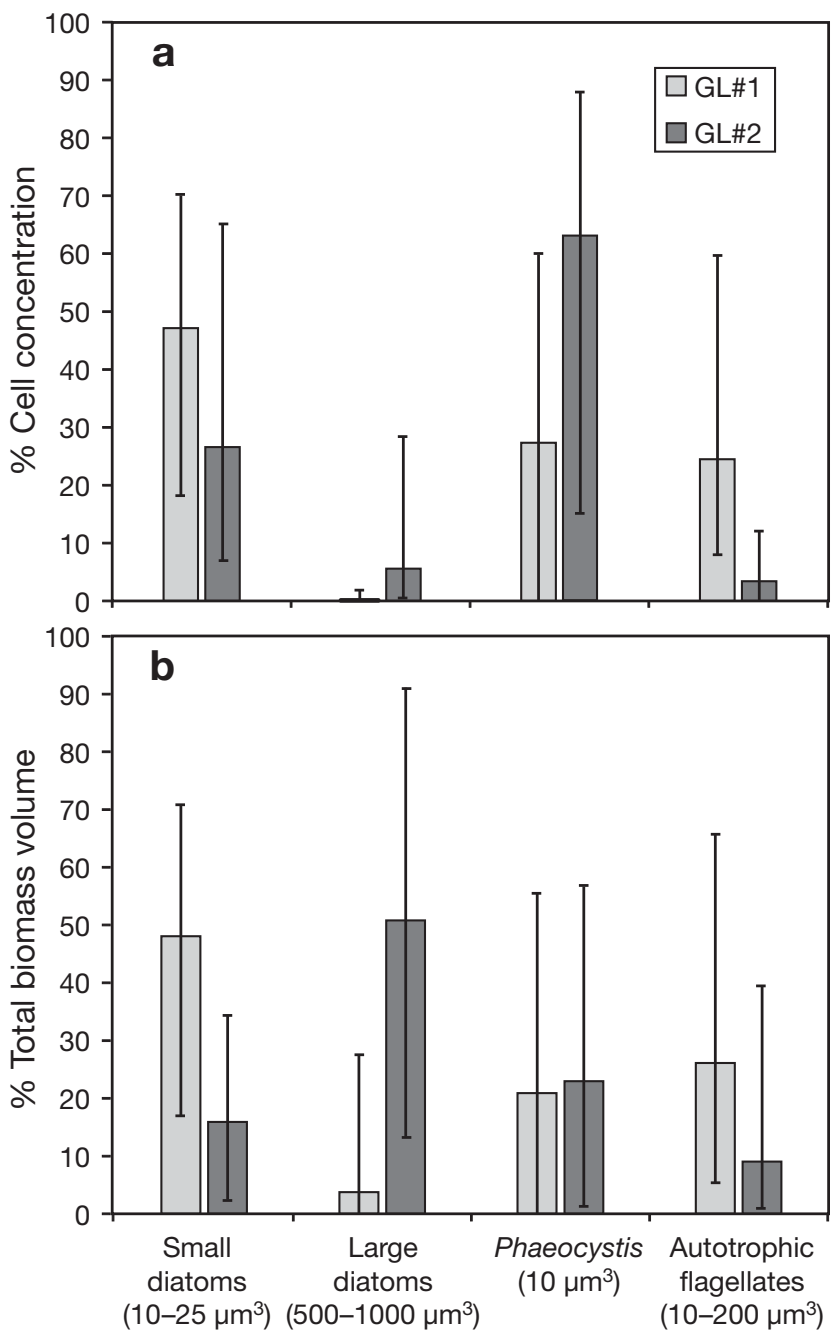

Fig. 2. (a) Cell concentration and (b) biomass volume, expressed as percent of the total autotrophic protist abundance

tion of the data, the total biomass volume of diatoms and Phaeocystis correlated significantly with chl a $\left(\mathrm{r}_{\log -\log }=0.809\right.$ and 0.706 , respectively; $\left.\mathrm{p}<0.001\right)$, POC $\left(r_{\log -\log }=0.714\right.$ and 0.800 , respectively; $\left.\mathrm{p}<0.001\right)$ and $\mathrm{PN}\left(\mathrm{r}_{\log -\log }=0.510, \mathrm{p}=0.015\right.$, and $\mathrm{r}_{\log -\log }=0.605, \mathrm{p}=$ 0.004, respectively).

\section{DISCUSSION}

\section{Biogenic particles}

The measured compositional characteristics of the biogenic matter outlined above were derived from the particles suspended in the gap water. In addition to the active and inactive organisms in the water, this material also reflects the equivalent components on and within the upper and lower ice boundaries of the gaps, 
due to random contribution from the biogenic matter therein during the formation and development of these surface sea ice features. Thus, the measurements offer a qualitative description of the microbial assemblage within the upper sea ice layers, which often harbour excessive biomass accumulation as the productive season advances (Kennedy et al. 2002, Kattner et al. 2004). Diatoms in GL\#1, along with the prymnesiophyte Phaeocystis in GL\#2, dominated cell concentration and total biomass volume in the primarily autotrophic biological assemblages of the present study (Fig. 2), with flagellated species (dinoflagellates, Mantoniella sp.) always present. The autotrophic microbial assemblages in the gap layers exhibited the same principal taxonomic structure as Antarctic shelf waters, where diatoms and Phaeocystis are the 2 major taxa responsible for phytoplankton blooms and organic carbon export (Arrigo et al. 1999, DiTullio et al. 2000). The heterotrophic protist biomass was comparatively minor, suggesting only small, if any, grazing pressure on the developing microbial assemblages at the time of the study.

The abundance of diatoms and Phaeocystis, expressed as total biomass volume, covaried with the concentrations of chl $a$, POC, and PN, which underlines the distinctive control of these 2 predominant taxa on the suspended particle-derived and biomass-related geo-
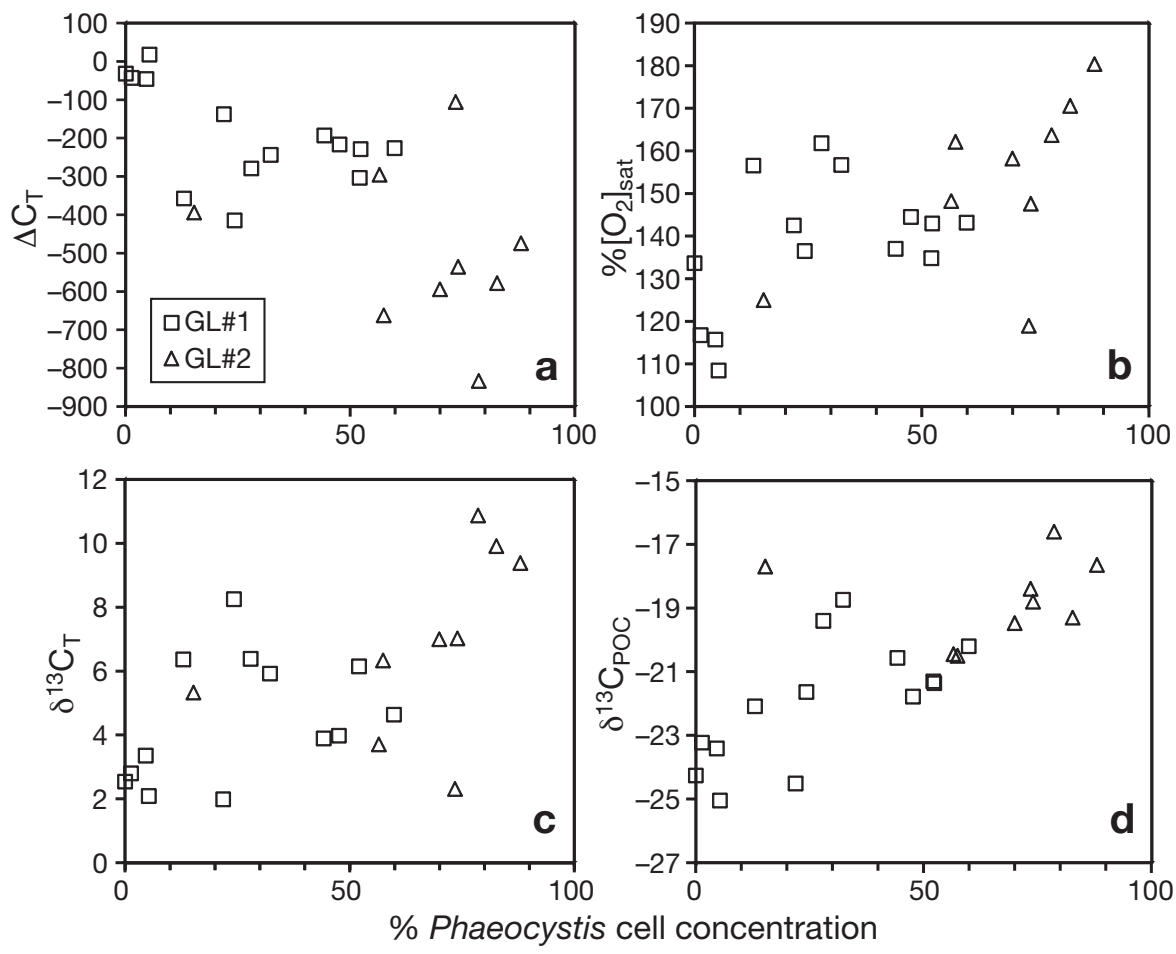

Fig. 3. (a) Dissolved inorganic carbon deficit, $\Delta \mathrm{C}_{\mathrm{T}}$, (b) percent $\mathrm{O}_{2}$ saturation, $\%\left[\mathrm{O}_{2}\right]_{\text {sat, }}$ (c) the stable isotopic composition of total dissolved inorganic carbon, $\delta^{13} \mathrm{C}_{\mathrm{T}}$ and (d) the stable isotopic composition of particulate organic carbon, $\delta^{13} \mathrm{C}_{\mathrm{POC}}$ as a function of the percent cell concentration of Phaeocystis chemical parameters. Further, the cell concentration of Phaeocystis, normalised to the total cell concentration of all autotrophic species present, covaried with $\Delta \mathrm{C}_{\mathrm{T}}$ $(\mathrm{r}=-0.636, \mathrm{p}=0.001)$, the increase in the $\mathrm{O}_{2}$ concentration relative to that at air saturation $\left(\left[\% \mathrm{O}_{2}\right]_{\text {sat }} ; \mathrm{r}=0.542\right.$, $\mathrm{p}=0.009), \delta^{13} \mathrm{C}_{\mathrm{T}}(\mathrm{r}=0.593, \mathrm{p}=0.004)$ and $\delta^{13} \mathrm{C}_{\mathrm{POC}}(\mathrm{r}=$ $0.722, p<0.001 ;$ Fig. 3$)$. This suggests that the influence of the suspended Phaeocystis cells extended into the dissolved and isotopic pools of inorganic carbon in the gap waters, as well as into the isotopic composition of the POC. Increasing $\mathrm{C}_{\mathrm{T}}$ deficit and isotopic enrichment, as well as increasing $\mathrm{O}_{2}$ saturation and isotopic enrichment of POC, were all associated with increasing abundance of Phaeocystis cells.

An important feature of the 2 surface gap layers in the current study was their difference with respect to several components of the pool of biogenic matter. Specifically, the concentrations of chl $a, \mathrm{POC}, \mathrm{PN}$ and DOC were significantly lower in GL\#1 than in GL\#2 ( $\mathrm{p} \leq$ 0.001; Table 1). The biogenic parameters did not show a discernible temporal trend in either habitat (Fig. 1), and their outlined differences were sustained throughout the observational period. Significant dissimilarity was also evident in the POC:chl a $(\mathrm{p}<0.001)$ but not in the POC:PN ( $p=0.298$; Table 1). The measured POC:chl a were in the range previously reported for late summer Antarctic sea ice (Kennedy et al. 2002) and suggest the presence of chlorophyll-poor (non-photosynthetic) biogenic particles in the comparatively small particulate organic matter (POM) pool suspended in GL\#1, with more chlorophyll-rich biogenic particles in the larger POM pool suspended in GL\#2. However, both low temperature and high irradiance, incident near the surface of sea ice, can also result in high POC:chl a (Geider 1987).

\section{Inorganic nutrient deficit}

The measured increase in $\left[\% \mathrm{O}_{2}\right]_{\text {sat }}$ was significantly correlated with the increase in $\mathrm{pH}_{\mathrm{SWS}}(\mathrm{r}=0.641, \mathrm{p}=0.001)$ and the decrease in $\mathrm{C}_{\mathrm{T}}(\mathrm{r}=-0.732, \mathrm{p} \leq$ $0.001)$, as well as the decrease in $\mathrm{CO}_{2}$ (aq) ( $\mathrm{r}_{\text {log-log }}=-0.621, \mathrm{p}=0.002$ ). These relationships, coupled with the severe reduction in the concentration of the major dissolved inorganic macro-nutrients relative to surface oceanic water (Table 1), comprise the geochemical signature of a closed or semi-closed net autotrophic environ- 
ment. Such drastic chemical changes, also coincident with the large ${ }^{13} \mathrm{C}$ shifts, suggest either restricted solute replenishment from the surface oceanic pool or that the rate of primary production by the surface ice algae exceeded it considerably. Despite the differences in the composition of the suspended POM outlined earlier, both gaps exhibited uniformly elevated $\mathrm{O}_{2}, \mathrm{pH}_{\mathrm{SwS}}$ and $\delta^{13} \mathrm{C}_{\mathrm{T}}$, as well as similarly reduced concentrations of dissolved inorganic nutrients, implying equivalent net autotrophic activity. The measured changes in the dissolved constituents integrate the effects of, and thus afford a more quantitative outlook onto, the activity of the total surface sea ice community that is fuelled by the resources available in the gap water.

If the stoichiometric ratio of the biological nutrient uptake is constant in space and time, inter-nutrient linear trends can be expected in the deviation $(\Delta \mathrm{C})$ of the residual concentrations from that in surface seawater, with a slope equivalent to the stoichiometry of the bio- logical reaction. The physical-biogeochemical scenario described by Eq. (2) yielded significant linear correlations among $\Delta \mathrm{C}_{\mathrm{T}}, \Delta \mathrm{NO}_{3}{ }^{-}$and $\Delta \mathrm{SRP}$ (Fig. 4). Although the anticipated inverse trend in the distribution of $\Delta \mathrm{O}_{2}$ relative to $\Delta \mathrm{C}_{\mathrm{T}}$ was evident (Fig. $4 \mathrm{~d}$ ), their correlation was not significant $(\mathrm{r}=-0.284, \mathrm{p}=0.189, \mathrm{n}=23)$. While the $\Delta \mathrm{C}_{\mathrm{T}}$ and $\Delta \mathrm{O}_{2}$ observations from GL\#1 were clustered around the Redfield photosynthetic quotient of $\Delta \mathrm{C}_{\mathrm{T}}: \Delta \mathrm{O}_{2}=-106: 138=-0.768$ (Fig. $4 \mathrm{~d}$ ), the concentration changes in GL\#2 were offset, indicating only a small $\mathrm{O}_{2}$ accumulation for the large $\mathrm{C}_{\mathrm{T}}$ deficit in the gap water at that location in the ice floe. Decoupling of $\mathrm{O}_{2}$ from $\mathrm{C}_{\mathrm{T}}$ dynamics can arise either from $\mathrm{O}_{2}$ degassing or an additional $\mathrm{C}_{\mathrm{T}}$ sink within the system.

Regression analysis on the significant inter-nutrient linear correlations indicates that for a $\Delta \mathrm{C}_{\mathrm{T}}=0, \Delta \mathrm{NO}_{3}{ }^{-}=$ $-17 \pm 2$ and $\Delta \mathrm{SRP}=-1.3 \pm 0.1$. This suggests that, for a $\mathrm{C}_{\mathrm{T}}$ concentration in the gap waters equivalent to that in the surface oceanic water, i.e. for no net inorganic carbon deficit, the $\mathrm{NO}_{3}{ }^{-}$and SRP concentrations were
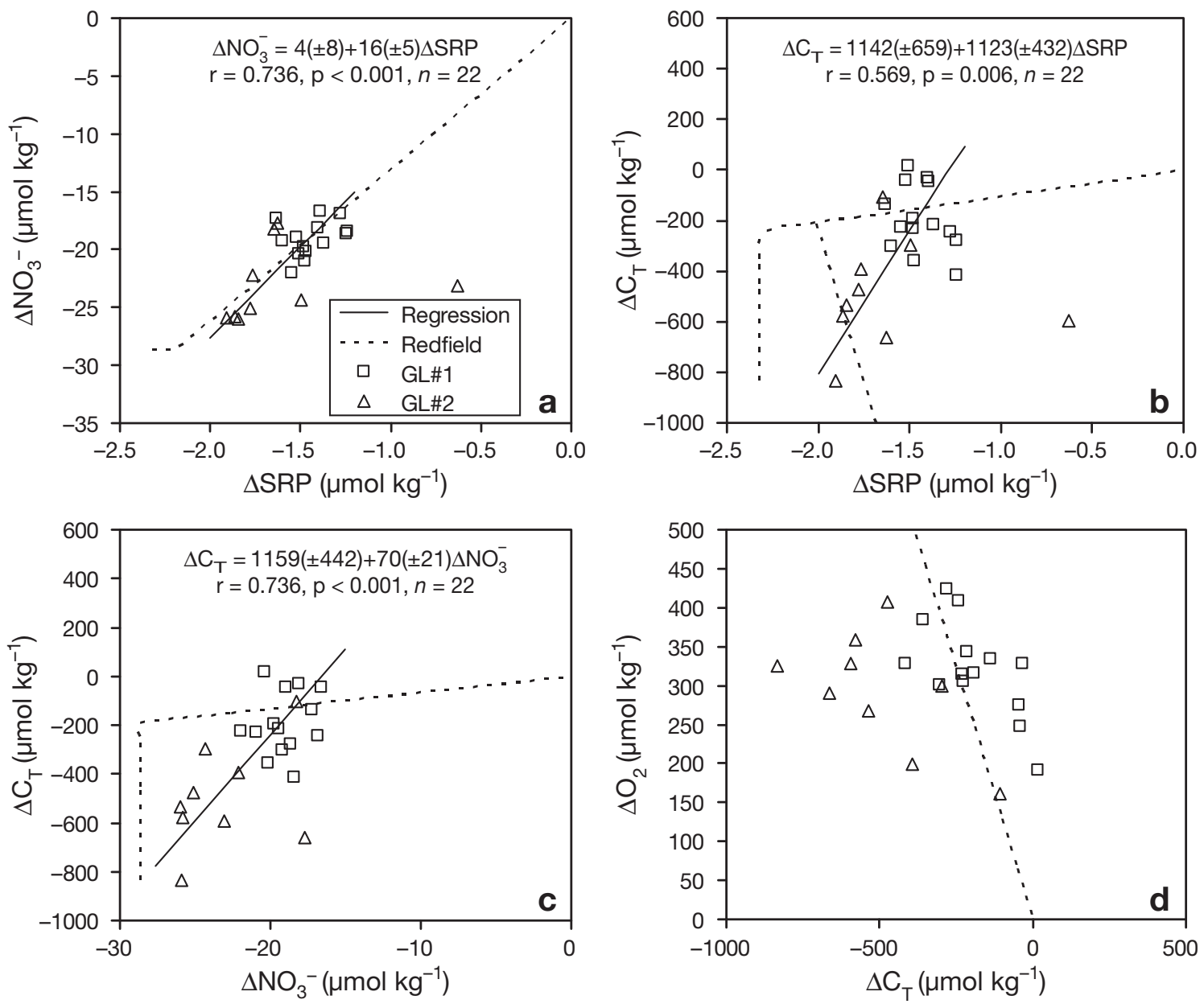

Fig. 4. (a) Nitrate deficit, $\Delta \mathrm{NO}_{3}{ }^{-}$, and (b) dissolved inorganic carbon deficit, $\Delta \mathrm{C}_{\mathrm{T}}$, versus dissolved inorganic phosphorus deficit, $\Delta \mathrm{SRP} ;$ (c) dissolved inorganic carbon deficit, $\Delta \mathrm{C}_{\mathrm{T}}$, versus nitrate deficit, $\Delta \mathrm{NO}_{3}{ }^{-}$, and (d) excess dissolved molecular oxygen, $\Delta \mathrm{O}_{2}$, versus dissolved inorganic carbon deficit, $\Delta \mathrm{C}_{\mathrm{T}}$ 
already both comparatively reduced by more than $50 \%$, as illustrated in the offset of the trends from the origin of the axes in Fig. 4b,c. The slopes of the linear regressions (Fig. 4a,b) translate into a mean $\mathrm{C}: \mathrm{N}: \mathrm{P}=$ $1123 \pm 432: 16 \pm 5: 1$ for the inorganic nutrient deficit. This indicates that while the N:P of the nutrient deficit in the gap waters is similar to that predicted from the $\mathrm{C}: \mathrm{N}: \mathrm{P}=106: 16: 1$ of the global pelagic plankton community (Redfield ratio; Fig. 4a) and the mean C:N:P = 114.0:16.4:1.0 of the marine POM (Geider \& LaRoche 2002), the inorganic carbon deficit is 1 order of magnitude greater. The observed $\Delta \mathrm{C}_{\mathrm{T}}$ is equivalent to a deficit generated by excess biological inorganic carbon fixation after the available inorganic nitrogen and phosphorus stocks are depleted in the predicted Redfield trends (Fig. 4b,c). Higher autotrophic $\mathrm{C}_{\mathrm{T}}$ consumption than predicted by the Redfield stoichiometric conversion of the deficit in the $\mathrm{NO}_{3}{ }^{-}$stock has been termed carbon overconsumption (Toggweiler 1993), ranging from 17 to $300 \%$ in surface oceanic conditions of bloom and post-bloom nutrient depletion (Sambrotto et al. 1993, Engel et al. 2002). Carbon overconsumption was calculated from individual observations to range from 30 to $600 \%$ in the gap waters and has been reported previously from changes in the dissolved inorganic nutrient stocks in ice floes during summer and autumn (Gleitz et al. 1995, 1996a). It has been attributed to the biological production of carbohydrates (Engel et al. 2002, Schartau et al. 2007) and lipids, the latter compounds previously observed concentrated in cell stores in nitrogen-deficient conditions in sea ice habitats (Gleitz et al. 1996a), while both useful for survival, among other functions, as carbon-rich energy reserves (Geider \& LaRoche 2002).

The $\mathrm{C}: \mathrm{N}=70 \pm 21$ calculated from the inorganic nutrient deficit (Fig. 4c) is greater by a factor of 2 to 9 in comparison to the elemental composition of the bulk POM reflected in the measured POC:PN (Table 1). The stoichiometries of the POM and the inorganic nutrient uptake, and their relationship, depend on the structure of the microbial community, the physiology of its members, and their varying and variable nutrient requirements prescribed by the growth phase, growth strategy and ecological conditions (Geider \& LaRoche 2002, Klausmeier et al. 2004, Arrigo 2005). To the extent that the measured elemental composition of the POM is representative of the dominant autotrophic contingent of the bulk biological community in the surface sea ice layers, its lower $\mathrm{C}: \mathrm{N}$ relative to that of the inorganic nutrient deficit suggests that approximately $80 \%$ of the inorganic carbon uptake is exuded as extracellular DOC. Sea ice diatoms and Phaeocystis, the 2 predominant microalgal taxa, are known to drive excessive inorganic carbon uptake for the synthesis of extracellular, carbon-rich (low molecular weight carbohydrates), colony-forming organic matter, which may be partially recovered in the DOC pool depending on sampling strategy (Krembs \& Deming 2008). A small but significant part of the total cell abundance of Phaeocystis in the present study was observed in small colonies. The calculated $\triangle \mathrm{DOC}$ was $8 \pm 5 \%$ (range: 2 to $15 \%$ ) and $23 \pm 24 \%$ (range: 4 to $65 \%$ ) of $\Delta \mathrm{C}_{\mathrm{T}}$ in GL\#1 and GL\#2, respectively. The small and only occasionally significant contribution of DOC to the carbon pool of this system cannot alone fully explain the stoichiometric discrepancy between the elemental POM composition and water chemistry.

Alternatively, or in addition to the above considerations, a fraction of the autotrophic nitrogen requirement was derived from an additional source other than $\mathrm{NO}_{3}{ }^{-}$, such as $\mathrm{NH}_{4}{ }^{+}$and urea. Although $\mathrm{NO}_{3}{ }^{-}$has been found to be the major nitrogen source in taxonomically similar infiltration communities early in the growing season, $\mathrm{NH}_{4}{ }^{+}$and urea can also be used as substrates for autotrophic growth, and increasingly more so following $\mathrm{NO}_{3}{ }^{-}$depletion as the growing season progresses (Kristiansen et al. 1998). The presence and, especially, accumulation of $\mathrm{NH}_{4}{ }^{+}$and urea in aqueous media are manifestations of metabolism of organic nitrogen, with sympagic zooplankton a notable source of both via excretion in our case study (Bamstedt 1985, SchnackSchiel et al. 2001, 2004). Both of these compounds were in measurable quantities in the gap waters, comparable to those previously observed in similar sea ice habitats (Kristiansen et al. 1998), but, as described earlier, only urea was systematically enriched relative to surface seawater. Resolution of the observed discrepancy between the mean POC:PN (Table 1) and $\Delta \mathrm{C}_{\mathrm{T}}: \Delta \mathrm{NO}_{3}{ }^{-}=$ $70 \pm 21$ with supplementary nitrogen uptake in the form of $\mathrm{NH}_{4}{ }^{+}$and urea- $\mathrm{N}$ requires starting concentrations equivalent to approximately 5 to $6 \%$ of $\Delta \mathrm{C}_{\mathrm{T}}$ prior to our observation period, i.e. in excess of $7 \mu \mathrm{mol} \mathrm{kg} \mathrm{kg}^{-1}$ and up to 20 and $50 \mu \mathrm{mol} \mathrm{kg}{ }^{-1}$ in GL\#1 and GL\#2, respectively. Urea is a specialist parameter, and little is known about it in sea ice by comparison to the routinely measured $\mathrm{NH}_{4}{ }^{+}$, for which concentrations of this magnitude have been typically measured in internal sea ice brines and under-ice platelet layers (Gleitz et al. 1995, Arrigo et al. 2003, Schnack-Schiel et al. 2004) rather than in gap waters (Kattner et al. 2004). Clearly, this issue cannot be resolved with the present data set and remains a possibility.

The $\mathrm{C}_{\mathrm{T}}$ pool in the gap waters was ${ }^{13} \mathrm{C}$-enriched in comparison to the $\delta^{13} C_{\mathrm{T}}$ in surface seawater (Fig. 1a) and in the world oceans (Kroopnick 1985: -0.5 to $+1.5 \%$ ). The current $\delta^{13} \mathrm{C}_{\mathrm{T}}$ data (+2.0 to $+10.9 \%$ ) indicate a more dramatic isotopic enrichment than previously observed in similar productive sea ice habitats (Thomas et al. 2001: +0.4 to $+3.8 \%$; Kennedy et al. $2002:+0.2$ to $+3.0 \%$ o) and in internal brines from the 
same floe (Papadimitriou et al. 2007: +2.9 to $+6.4 \%$ ). The $\delta^{13} C_{\mathrm{POC}}$ was within the range of previously reported values from surface sea ice habitats in the Weddell Sea in the summer (Kennedy et al. 2002; see Fig. 6) and from bottom first-year sea ice communities in the Ross Sea (Arrigo et al. 2003: range: -27.3 to $-17.2 \%$ ) but tended to be higher (more ${ }^{13} \mathrm{C}$-enriched) than previous measurements from sea ice in the Weddell Sea (Rau et al. 1991: range -28.7 to $-22.3 \%$ ). The $\delta^{13} \mathrm{C}_{\mathrm{T}}$ observations correlated significantly ( $\mathrm{p} \leq 0.001$, $\mathrm{n}=23)$ with $\%\left[\mathrm{O}_{2}\right]_{\text {sat }}(\mathrm{r}=0.756), \mathrm{pH}_{\mathrm{SwS}}(\mathrm{r}=0.817)$, and $\Delta \mathrm{C}_{\mathrm{T}}(\mathrm{r}=-0.877)$, and the $\delta^{13} \mathrm{C}_{\mathrm{POC}}$ correlated significantly with $\Delta \mathrm{C}_{\mathrm{T}}(\mathrm{r}=0.695)$ and $\delta^{13} \mathrm{C}_{\mathrm{T}}(\mathrm{r}=0.673$; Fig. 5).

The observed magnitude of the $\delta^{13} \mathrm{C}_{\mathrm{T}}$ enrichment in the gap waters (Fig. 1a) is similar to that predicted for primary production by diatoms in closed system laboratory incubations (Gleitz et al. 1996b). The $\delta^{13} \mathrm{C}_{\mathrm{T}}$ enrichment in the gap waters is a consequence of excessive biological demand for inorganic carbon relative to its supply, generating a semblance of closed system conditions in the gap layers rather than isolation per se. This is because gap water exchanges regularly with the surface oceanic water and with the pool of particulate matter in the adjacent ice-water interfaces. With this caveat in mind, the isotopic mass balance approach for a closed system by Gleitz et al. (1996b) can be used to evaluate the outlined co-variation of $\delta^{13} \mathrm{C}_{\mathrm{POC}} \Delta \mathrm{C}_{\mathrm{T}}$ and $\delta^{13} \mathrm{C}_{\mathrm{T}}$ in the gap waters.

$$
\begin{gathered}
\delta^{13} \mathrm{C}_{\mathrm{T}}=\frac{\delta^{13} \mathrm{C}_{\mathrm{T}_{\mathrm{o}}}+\delta^{13} \mathrm{C}_{\mathrm{POC}_{\text {new }}} \frac{\Delta \mathrm{C}_{\mathrm{T}}}{\mathrm{C}_{\mathrm{T}_{\mathrm{o}}}}}{1+\frac{\Delta \mathrm{C}_{\mathrm{T}}}{\mathrm{C}_{\mathrm{T}_{\mathrm{o}}}}} \text {, with } \Delta \mathrm{C}_{\mathrm{T}} \leq 0 \\
\mathrm{POC}_{\mathrm{T}} \delta^{13} \mathrm{C}_{\mathrm{POC}_{\mathrm{T}}}=\mathrm{POC}_{\mathrm{o}} \delta^{13} \mathrm{C}_{\mathrm{POC}_{\mathrm{o}}}+\mathrm{POC}_{\text {new }} \delta^{13} \mathrm{C}_{\mathrm{POC}_{\text {new }}}
\end{gathered}
$$

Eq. (3) describes the $\delta^{13} C_{T}$ in a closed system as a function of the initial $\mathrm{C}_{\mathrm{T}}$ conditions $\left(\mathrm{C}_{\mathrm{T}_{0}} \delta^{13} \mathrm{C}_{\mathrm{T}_{0}}\right), \Delta \mathrm{C}_{\mathrm{T}}$ and the isotopic composition of the new biomass $\left(\delta^{13} \mathrm{C}_{\mathrm{POC}_{\text {new }}}\right)$. Similarly, the $\delta^{13} \mathrm{C}_{\mathrm{POC}_{\text {new }}}$ can be estimated from the isotopic mass balance of carbon in the particulate phase (Eq. 4). Due to the sampling constraints outlined earlier, the total carbon biomass $\left(\mathrm{POC}_{\mathrm{T}}\right)$ and its isotopic composition $\left(\delta^{13} \mathrm{C}_{\mathrm{POC}_{\mathrm{T}}}\right)$ of the whole of the community in the surface gap layers are not known. Assuming that the $\delta^{13} \mathrm{C}_{\mathrm{POC}}$ measured in the suspensions of the gap waters is representative of the $\delta^{13} \mathrm{C}_{\mathrm{POC}_{\mathrm{T}}}$ and assigning the observed $\mathrm{C}_{\mathrm{T}}$ deficit to new biomass $\left(\mathrm{POC}_{\text {new }}=\Delta \mathrm{C}_{\mathrm{T}}\right.$, and $\mathrm{POC}_{\mathrm{T}}=\mathrm{POC}_{\mathrm{o}}+\Delta \mathrm{C}_{\mathrm{T}}$ in Eq. $4)$, the $\delta^{13} C_{T}$ can be predicted from the $\Delta C_{T}$ observations and the average, as well as the range, of $\delta^{13} \mathrm{C}_{\mathrm{POC}_{\text {new }}}$ estimates (Eq. 3) derived from the $\Delta \mathrm{C}_{\mathrm{T}}$ and $\delta^{13} \mathrm{C}_{\mathrm{POC}}$ observations (Eq. 4). The dynamics of the stable carbon isotopes during photosynthesis reflect organism metabolism and environmental (nutrient and irradiance) conditions (Cassar et al. 2006), such that the isotopic composition of new biomass is variable in response to several physiological and environmental factors. Growth rate, taxon-specific morphological and physiological differences in mixed microalgal assemblages, the availability of extracellular $\mathrm{CO}_{2}(\mathrm{aq})$, and induction of active uptake of $\mathrm{CO}_{2}$ or $\mathrm{HCO}_{3}{ }^{-}$by the cell regulate the kinetics of assimilation of the stable carbon isotopes during photosynthesis in experimental and natural systems (Burkhardt et al. 1999, Cassar et al. 2006). Ultimately, the shifting balance between the extracellular inorganic carbon supply and intracellular demand during microalgal growth modifies the expression of the enzymatic isotope effect in new biomass. Hence, the $\delta^{13} \mathrm{C}_{\mathrm{POC}_{\text {new }}}$ in the above model represents a simplistic average value for a given $\Delta \mathrm{C}_{\mathrm{T}}$. In this light, the distribution of the observed $\delta^{13} \mathrm{C}_{\mathrm{POC}}$ relative to $\Delta \mathrm{C}_{\mathrm{T}}$ shown in Fig. 5 a becomes equivalent to the mix-
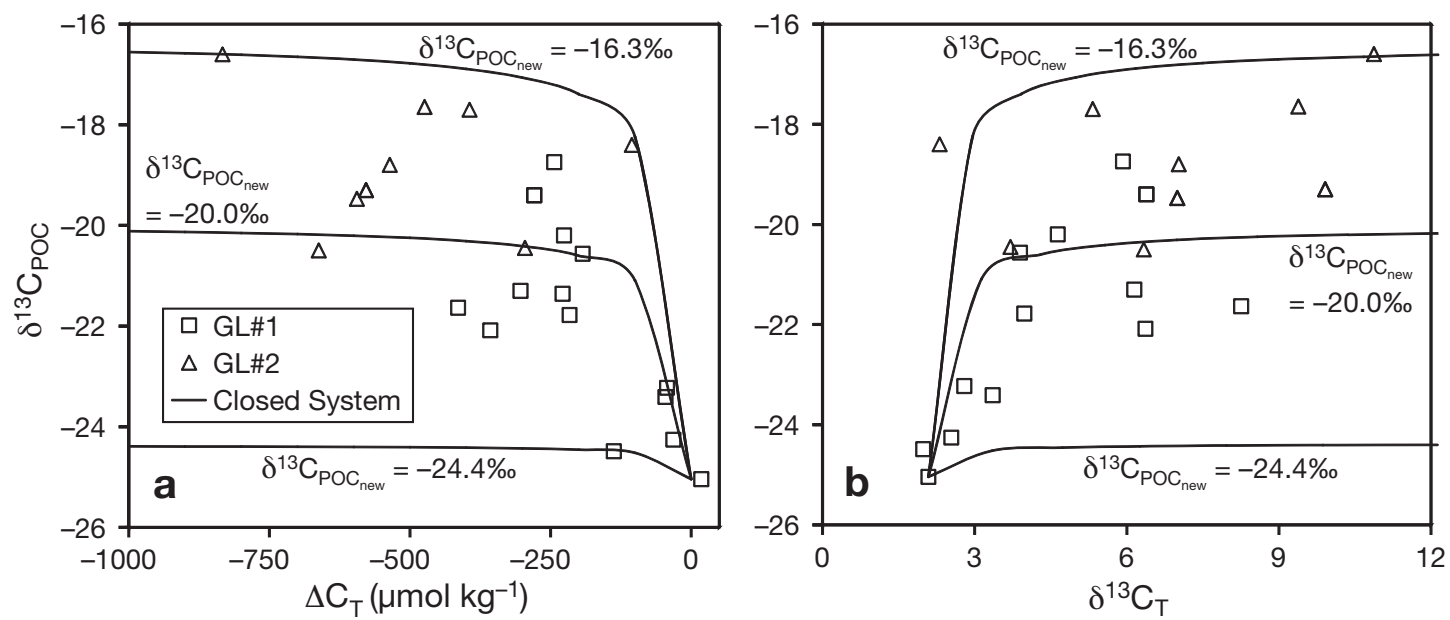

Fig. 5. Stable isotope composition of particulate organic carbon, $\delta^{13} \mathrm{C}_{\mathrm{POC}}$, as a function of (a) the dissolved inorganic carbon deficit, $\Delta \mathrm{C}_{\mathrm{T}}$, and (b) the stable isotopic composition of total dissolved inorganic carbon, $\delta^{13} \mathrm{C}_{\mathrm{T}}$. The curves are based on the closed system model described by Eqs. (3) \& (4) 
ing of 2 end-members, a ${ }^{13} \mathrm{C}$-enriched new biomass and a ${ }^{13} \mathrm{C}$-depleted $\left(\delta^{13} \mathrm{C}_{\mathrm{POC}_{\mathrm{o}}} \leq-25 \%\right.$ o) seed population $\left(\mathrm{POC}_{\mathrm{o}}=28 \mu \mathrm{mol} \mathrm{kg}{ }^{-1}\right)$ in the gap layers coupled with $\Delta \mathrm{C}_{\mathrm{T}} \approx 0\left(\mathrm{C}_{\mathrm{T}_{\mathrm{o}}}=2218 \mu \mathrm{mol} \mathrm{kg} \mathrm{kg}^{-1}, \delta^{13} \mathrm{C}_{\mathrm{T}_{\mathrm{o}}}=+2.1 \% \mathrm{o}\right)$, with current estimates of initial conditions derived from the earliest observations in GL\#1. The model and observations indicate that the new biomass was sufficiently depleted isotopically relative to the $\mathrm{C}_{\mathrm{T}}$ reservoir to cause the large shift observed in the $\delta^{13} C_{T}$ of the gap water (Figs. 1a, 5) but nonetheless generated a notable ${ }^{13} \mathrm{C}$ accumulation in the suspended POC pool in tandem with the isotopic enrichment of the bulk substrate (Fig. 5b).

The maximum isotopic enrichment of both the $C_{T}$ and POC pools, attained at maximum $\mathrm{C}_{\mathrm{T}}$ deficit (Fig. $5 a)$, was also related with the lowest concentrations $\left(<2 \mu \mathrm{mol} \mathrm{kg} \mathrm{kg}^{-1}\right.$ ) of $\mathrm{CO}_{2}$ (aq) in the system (Fig. 6). Although the concentration of extracellular $\mathrm{CO}_{2}$ (aq) is not the only factor controlling the $\delta^{13} \mathrm{C}$ of the autotrophic biomass, nor is $\mathrm{CO}_{2}(\mathrm{aq})$ the only $\mathrm{C}_{\mathrm{T}}$ species used by microalgae, it can be used to indicate the net availability of $\mathrm{CO}_{2}$ for biosynthesis in the habitat. Comparison to available coupled $\delta^{13} \mathrm{C}_{\mathrm{POC}}$ and $\mathrm{CO}_{2}(\mathrm{aq})$ observations from both surface sea ice habitats (this study, Kennedy et al. 2002) and the surface of the polar Southern Ocean (south of $60^{\circ} \mathrm{S}$ ) during the growing season (Kennedy \& Robertson 1995, Dehairs et al. 1997, Popp et al. 1999) shows that the sea ice-related microalgal assemblages comprise a distinct biogeochemical province from the oceanic phytoplankton, with surface sea ice habitats often exhibiting the lowest end of the spectrum of extracellular $\mathrm{CO}_{2}(\mathrm{aq})$ concentrations coupled with the most ${ }^{13} \mathrm{C}$-enriched POC in the polar oceanic system as a whole (Fig. 6). Although intermittent replenishment of the surface sea ice habitats with surface oceanic water can lead to excursions of highly ${ }^{13} \mathrm{C}$-enriched POC bathed in gap waters with elevated $\mathrm{CO}_{2}(\mathrm{aq})$ concentrations typical of surface oceanic water, the major part of the data demonstrates the high inorganic carbon demand of algal communities in sea ice relative to its supply from the surrounding medium. Comparative isotopic enrichment of POC at maximum biomass accumulation also appears to hold for internal and bottom sea ice microbial assemblages (Rau et al. 1991, Arrigo et al. 2003) and may characterise sea ice in general as a biome.

\section{CONCLUSIONS}

The biogeochemical composition of the aqueous phase of 2 spatially separate surface gap layers monitored over $13 \mathrm{~d}$ on a single Antarctic sea ice floe during early austral summer was dominated by autotrophic microbial assemblages, with diatoms and Phaeocystis providing the principal taxonomic structure. Despite the potential for exchange with surface oceanic water, the gap water exhibited the large geochemical changes typical of intense autotrophic activity, including a large deficit in all major dissolved inorganic nutrients, $\mathrm{O}_{2}$ accumulation above air saturation, large $\mathrm{pH}$ shifts towards alkaline values, and large isotopic shifts towards ${ }^{13} \mathrm{C}$ enrichment of the $\mathrm{C}_{\mathrm{T}}$ pool and the accumulated $\mathrm{POC}$, in all cases, relative to the composition of surface oceanic water. It is evident that the composition of the aqueous phase of both gaps was controlled by a uniformly productive ice algal community extending into the surrounding ice. The amount of inorganic carbon removed from the gap waters greatly exceeded that which can be predicted from either deficits in the dissolved inorganic nitrogen or phosphorus concentrations and the mean elemental composition of oceanic phytoplankton. This stoichiometric deviation suggests either (1) the operation of the inorganic carbon overconsumption mechanism via the biological production of particular classes of intra- or

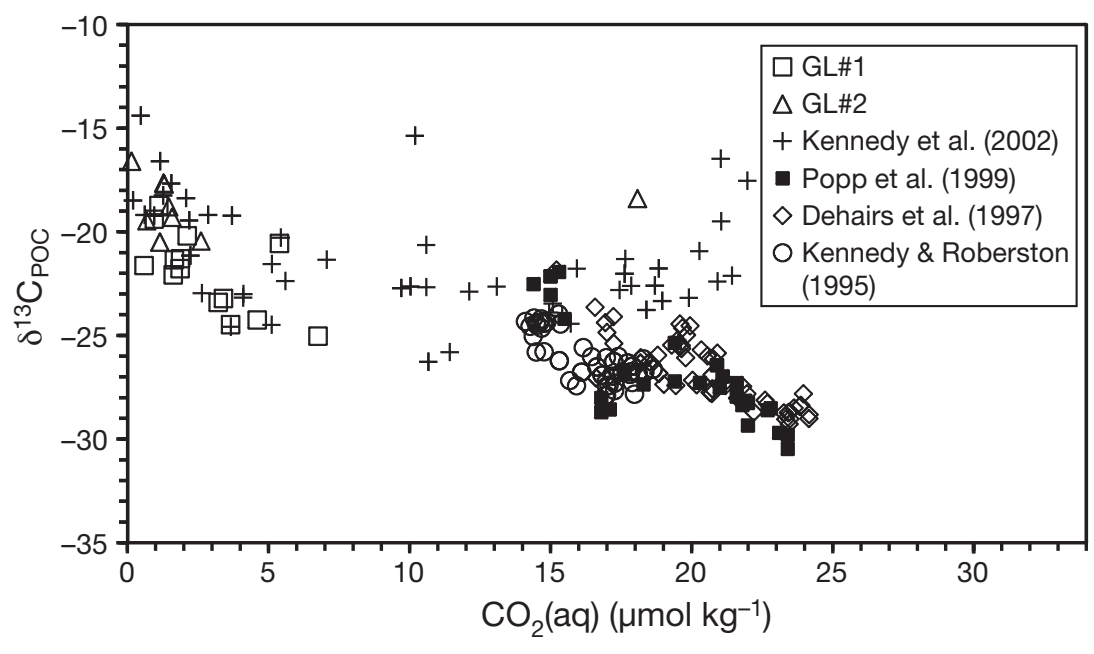

Fig. 6. Stable isotope composition of particulate organic carbon, $\delta^{13} \mathrm{C}_{\mathrm{POC}}$, as a function of dissolved $\mathrm{CO}_{2}$ in surface sea ice habitats from this study (GL\#1 and GL\#2) and from Kennedy et al. (2002), as well as in the surface of the circumpolar Southern Ocean south of $60^{\circ} \mathrm{S}$ taken from Kennedy \& Robertson (1995) (Pacific sector and Bellingshausen Sea, December 1993), Dehairs et al. (1997) (Indian sector and Prydz Bay, January 1991; Atlantic sector and eastern Weddell Sea, October to November 1992), and Popp et al. (1999) (Indian sector and Prydz Bay, January to March 1994) 
extracellular carbon-rich compounds seen elsewhere in the surface ocean, or (2) substantial utilisation of $\mathrm{NH}_{4}{ }^{+}$and urea as autotrophic nitrogen sources in addition to $\mathrm{NO}_{3}{ }^{-}$, or (3) both. If the inorganic carbon overconsumption is a valid hypothesis, it was comparatively extreme in the small and mostly confined spatial scale of the surface sea ice habitats, and underlines the inaccuracy of predicting the dynamics of carbon from the inorganic nitrogen and phosphorus dynamics in autotrophic systems. Further, the accumulation of the excess carbon in biogenic matter was not part of the suspended POC and the DOC pools in the gap waters and, thus, may not readily exchange with the surface oceanic water during infiltration but only after sea ice melt.

Acknowledgements. We thank the master and crew of the RV 'Polarstern' for their help in making this sampling possible, as well as colleagues from the ISPOL team who helped in fieldwork activities. Support with preparation for the expedition and subsequent analyses was given by $M$. Nicolaus, A. Scheltz, A. Batzke, P. Kennedy, L. Norman, H. Betts, E. Allhusen, R. Thomas, P. Dennis, and A. Marca-Bell. We also thank 3 anonymous reviewers for their helpful comments. This project was supported by NERC, The Leverhulme Trust, and The Royal Society.

\section{LITERATURE CITED}

Ackley SF, Sullivan CW (1994) Physical controls on the development and characteristics of Antarctic sea ice biological communities-a review and synthesis. Deep-Sea Res 41: 1583-1604

> Ackley SF, Lewis MJ, Fritsen CH, Xie H (2008) Internal melting in Antarctic sea ice: development of "gap layers". Geophys Res Lett 35:L11503. doi:10.1029/2008GL033644

Arrigo KR (2005) Marine microorganisms and global nutrient cycles. Nature 437:349-355

Arrigo KR, Worthen DL, Lizotte MP, Dixon P, Dieckmann G (1997) Primary production in Antarctic sea ice. Science 276:394-397

Arrigo KR, Robinson DH, Worthern DL, Dunbar RB, DiTullio GR, VanWoert M, Lizotte MP (1999) Phytoplankton community structure and the drawdown of nutrients and $\mathrm{CO}_{2}$ in the Southern Ocean. Science 283:365-367

Arrigo KR, Robinson DH, Dunbar RB, Leventer AR, Lizotte MP (2003) Physical control of chlorophyll a, POC, and TPN distributions in the pack ice of the Ross Sea, Antarctica. J Geophys Res 108(C10):3316

Bamstedt U (1985) Seasonal excretion rates of macrozooplankton from the Swedish west coast. Limnol Oceanogr 30:607-617

Burkhardt S, Riebesell U, Zondervan I (1999) Effects of growth rate, $\mathrm{CO}_{2}$ limitation and cell size on the stable carbon isotope fractionation in marine phytoplankton. Geochim Cosmochim Acta 63:3729-3741

- Cassar N, Laws EA, Popp BN (2006) Carbon isotopic fractionation by the marine diatom Phaeodactylum tricornutum under nutrient- and light-limited growth. Geochim Cosmochim Acta 70:5323-5335

> Dehairs F, Kopczynska E, Nielsen P, Lancelot C, Bakker DCE, Koeve W, Goeyens L (1997) $\delta^{13} \mathrm{C}$ of Southern Ocean sus- pended organic matter during spring and early summer: regional and temporal variability. Deep-Sea Res II 44: $129-142$

DiTullio GR, Grebmeier GM, Arrigo KR, Lizotte MP and others (2000) Rapid and early export of Phaeocystis antarctica blooms in the Ross Sea, Antarctica. Nature 404: 595-598

Engel A, Goldthwait S, Passow U, Alldredge A (2002) Temporal decoupling of carbon and nitrogen dynamics in a mesocosm diatom bloom. Limnol Oceanogr 47:753-761

Fogel ML, Cifuentes LA (1993) Isotope fractionation during primary production. In: Engel MH, Macko SA (eds) Organic geochemistry: principles and applications. Plenum Press, New York, NY, p 73-98

Fritsen CH, Lytle VI, Ackley SF, Sullivan CW (1994) Autumn bloom of Antarctic pack-ice algae. Science 266:782-784

Fritsen CH, Ackley SF, Kremer JN, Sullivan CW (1998) Floodfreeze cycles and microalgal dynamics in Antarctic pack ice. In: Lizotte MP, Arrigo KR (eds) Antarctic sea ice: biological processes, interactions and variability. AGU, Washington, DC, Antarctic Res Ser 73:1-22

Fritsen CH, Coale SL, Neenan DH, Gibson AH, Garrison DL (2001) Biomass, production and microhabitat characteristics near the freeboard of ice floes in the Ross Sea, Antarctica, during the austral summer. Ann Glaciol 33: $280-286$

Garrison DL, Buck KR (1991) Surface-layer sea ice assemblages in Antarctic pack ice during the austral spring: environmental conditions, primary production and community structure. Mar Ecol Prog Ser 75:161-172

Garrison DL, Jeffries MO, Gibson A, Coale SL, Neenan D, Fritsen C, Okolodkov YB, Gowing MM (2003) Development of sea ice microbial communities during autumn ice formation in the Ross Sea. Mar Ecol Prog Ser 259:1-15

Garrison DL, Gibson A, Coale SL, Gowing MM, Okolodkov YW, Fritsen CH, Jeffries MO (2005) Sea ice microbial communities in the Ross Sea: autumn and summer biota. Mar Ecol Prog Ser 300:39-52

Geider RJ (1987) Light and temperature dependence of the carbon to chlorophyll a ratio in microalgae and cyanobacteria: implications for physiology and growth of phytoplankton. New Phytol 106:1-34

> Geider RJ, LaRoche J (2002) Redfield revisited: variability of $\mathrm{C}: \mathrm{N}: \mathrm{P}$ in marine microalgae and its biochemical basis. Eur J Phycol 37:1-17

Gleitz M, Rutgers van der Loeff M, Thomas DN, Dieckmann GS, Millero FJ (1995) Comparison of summer and winter inorganic carbon, oxygen and nutrient concentrations in Antarctic sea ice brines. Mar Chem 51:81-91

Gleitz M, Grossmann S, Scharek R, Smetacek V (1996a) Ecology of diatom and bacterial assemblages in water associated with melting summer sea ice in the Weddell Sea, Antarctica. Antarct Sci 8:135-146

> Gleitz M, Kukert H, Riebesell U, Dieckmann GS (1996b) Carbon acquisition and growth of Antarctic sea ice diatoms in closed bottle incubations. Mar Ecol Prog Ser 135:169-177

> Haas C, Thomas DN, Bareiss J (2001) Surface properties and processes of perennial Antarctic sea ice in summer. J Glaciol 47:613-625

> Haas C, Nicolaus M, Willmes S, Worby A, Flinspach D (2008) Sea ice and snow thickness and physical properties of an ice floe in the western Weddell Sea and their changes during spring warming. Deep-Sea Res II 55:963-974

> Hellmer HH, Haas C, Dieckmann GS, Schroder M (2006) Sea ice feedbacks observed in western Weddell Sea. EOS Trans Am Geophys Union 87:173-184

Hellmer HH, Schroder M, Haas C, Dieckmann GS, Spindler 
M (2008) The ISPOL drift experiment. Deep-Sea Res II 55: 913-917

Kattner G, Thomas DN, Haas C, Kennedy H, Dieckmann GS (2004) Surface ice and gap layers in Antarctic sea ice: highly productive habitats. Mar Ecol Prog Ser 277:1-12

Kennedy H, Robertson J (1995) Variations in the isotopic composition of particulate organic carbon in surface waters along an $88^{\circ} \mathrm{S}$ transect from $67^{\circ} \mathrm{S}$ to $54^{\circ} \mathrm{S}$. Deep-Sea Res II 42:1109-1122

Kennedy H, Thomas DN, Kattner G, Haas C, Dieckmann GS (2002) Particulate organic matter in Antarctic summer sea ice: concentration and stable isotopic composition. Mar Ecol Prog Ser 238:1-13

Klausmeier CA, Litchman E, Daufresne T, Levin SA (2004) Optimal nitrogen-to-phosphorus stoichiometry of phytoplankton. Nature 429:171-174

Kottmeier ST, Sullivan CW (1990) Bacterial biomass and production in pack ice of Antarctic marginal ice edge zones. Deep-Sea Res 37:1311-1330

Krembs C, Deming JW (2008) The role of exopolymers in microbial adaptations to sea ice. In: Margesin R, Schinner F, Marx JC, Gerday C (eds) Psychrophiles: from biodiversity to biotechnology. Springer-Verlag, Berlin, Heidelberg, p 247-264

Kristiansen S, Farbrot T, Kuosa H, Myklestad S, Quillfeldt CH (1998) Nitrogen uptake in the infiltration community, an ice algal community in Antarctic pack-ice. Polar Biol 19: 307-315

Kroopnick PM (1985) The distribution of ${ }^{13} \mathrm{C}$ of $\Sigma \mathrm{CO}_{2}$ in the world oceans. Deep-Sea Res 32:57-84

Lannuzel D, Schoemann V, de Jong J, Chou L, Delille B, Becquevort S, Tison JL (2008) Iron study during a time series in the western Weddell pack ice. Mar Chem 108:85-95

Lizotte MP, Sullivan CW (1991) Photosynthesis-irradiance relationships in microalgae associated with Antarctic pack ice: evidence for in situ activity. Mar Ecol Prog Ser 71: 175-184

Marion GM (2001) Carbonate mineral solubility at low temperatures in the Na-K-Mg-Ca-H-Cl- $\mathrm{SO}_{4}-\mathrm{OH}-\mathrm{HCO}_{3}$ $\mathrm{CO}_{3}-\mathrm{CO}_{2}-\mathrm{H}_{2} \mathrm{O}$ system. Geochim Cosmochim Acta 65: 1883-1896

Editorial responsibility: Hans Heinrich Janssen, Oldendorf/Luhe, Germany
Papadimitriou S, Thomas DN, Kennedy H, Haas C, Kuosa H, Krell H, Dieckmann GS (2007) Biogeochemical composition of natural sea ice brines from the Weddell Sea during early austral summer. Limnol Oceanogr 52: 1809-1823

Popp BN, Trull T, Kenig F, Wakeham SG and others (1999) Controls on the carbon isotopic composition of Southern Ocean phytoplankton. Global Biogeochem Cycles 13: $827-843$

Price NM, Harrison PJ (1987) Comparison of methods for the analysis of dissolved urea in seawater. Mar Biol 94: $307-317$

Rau GH, Sullivan CW, Gordon LI (1991) $\delta^{13} \mathrm{C}$ and $\delta^{15} \mathrm{~N}$ variations in Weddell Sea particulate organic matter. Mar Chem 35:355-369

Ricker WE (1973) Linear regressions in fishery research. J Fish Res Board Can 30:409-434

Sambrotto RN, Savidge G, Robinson C, Boyd P and others (1993) Elevated consumption of carbon relative to nitrogen in the surface ocean. Nature 363:248-250

Schartau M, Engel A, Schroter J, Thoms S, Volker C, WolfGladrow D (2007) Modelling carbon overconsumption and the formation of extracellular particulate organic carbon. Biogeosciences 4:433-454

Schnack-Schiel SB, Thomas DN, Haas C, Dieckmann GS, Alheit R (2001) The occurrence of the copepods Stephos longipes (Calanoida) and Drescheriella glacialis (Harpacticoida) in summer sea ice in the Weddell Sea, Antarctica. Antarct Sci 13:150-157

Schnack-Schiel SB, Dieckmann GS, Kattner G, Thomas DN (2004) Copepods in summer platelet ice in the eastern Weddell Sea, Antarctica. Polar Biol 27:502-506

Thomas DN, Kennedy H, Kattner G, Gerdes D, Gough C, Dieckmann GS (2001) Biogeochemistry of platelet ice: its influence on particle flux under fast ice in the Weddell Sea, Antarctica. Polar Biol 24:486-496

Tison JL, Worby A, Delille B, Brabant F and others (2008) Temporal evolution of decaying summer first-year sea ice in the Western Weddell Sea. Deep-Sea Res II 55:975-987

Toggweiler JR (1993) Carbon overconsumption. Nature 363: $210-211$

Submitted: October 15, 2008; Accepted: April 6, 2009 Proofs received from author(s): June 19, 2009 